\title{
HUBUNGAN ANTARA PEMBERIAN KREDIT DENGAN SISA HASIL USAHA PADA KOPERASI PEGAWAI REPUBLIK INDONESIA (KPRI) “ MARGA JAYA “ DI DESA DOPLANG KABUPATEN BLORA
}

\author{
Ulfah Rizkiani Nazhiroh \\ Mahasiswa Prodi. Pendidikan Ekonomi IKIP PGRI Madiun
}

\begin{abstract}
Abstrak. Tujuan dari penelitian ini adalah (1) Untuk menentukan jumlah Pinjaman di KPRI "MARGA JAYA" Jati Kecamatan Blora, (2) Untuk menentukan keseimbangan (SHU) pada KPRI Kecamatan "MARGA JAYA" Jati Blora, dan (3 ) Untuk Pinjaman Hubungan Antara mengetahui SHU di KPRI kecamatan "MARGA JAYA" Jati Blora. Penelitian ini mengambil obyek di kabupaten KPRI "MARGA JAYA" Jati dengan populasi Blora 21 (tahun). karena jumlah populasi kecil dalam penelitian ini semua populasi sampel adalah 21 (tahun). Data dikumpulkan melalui wawancara dan dokumentasi. Sementara alat analisis yang digunakan untuk menjawab hipotesis adalah uji korelasi product moment dan uji $\mathrm{t}$ atau uji berarti berbeda. Dari hasil perhitungan jumlah pengujian hipotesis telah diperoleh koefisien korelasi (r) dari 0,930. Ini adalah korelasi positif antara dua variabel, yaitu hubungan antara Lending $(\mathrm{X})$ dengan saldo $(\mathrm{Y})$ termasuk kategori sangat tinggi atau Kuat Sekali, dapat diandalkan. Berdasarkan penentuan hasil tes yang diperoleh R2 sebesar 0,865. Jadi kontribusi dari akuisisi SHU koperasi kredit yaitu sebesar 86,5\% sedangkan sisanya 13,5\% dipengaruhi oleh faktor lain. Dari hasil perhitungan perhitungan diperoleh $\mathrm{t}$ uji $\mathrm{t}$ untuk 11,315 sementara ttabel dengan derajat kebebasan $(\mathrm{db})=\mathrm{N}-(\mathrm{K}-1)$ untuk menguji arah $=21$ $(2-1)=20$ adalah sama dengan 1,725. Ini berarti bahwa $t_{\text {hitung }}>t_{\text {tabel }}(11,315>1,725)$. Atas dasar uji t dapat disimpulkan tolak Ho (Ha diterima), yang berarti bahwa ada perbedaan antara hubungan pinjaman dengan SHU pada KPRI "MARGA JAYA".
\end{abstract}

Kata kunci: Pinjaman, Hasil Usaha (SHU)

\section{PENDAHULUAN}

Koperasi merupakan suatu badan usaha bersama yang berjuang dalam bidang ekonomi. "Berdasarkan Undang-undang nomer 17 tahun 2012 pasal 1 tentang Perkoperasian bahwa Koperasi adalah badan hukum yang didirikan oleh orang perorangan atau badan hukum koperasi dengan pemisahan kekayaan para anggotanya sebagai modal untuk menjalankan usaha, yang memenuhi aspirasi dan kebutuhan bersama di bidang ekonomi, social, dan budaya sesuai dengan nilai dan prinsip koperasi".

Menurut Sitio dan Tamba (2001:16) “ koperasi dikaitkan dengan upaya kelompok- kelompok individu yang bermaksud mewujudkan tujuan-tujuan umum atau sasaran-sasaran konkritnya melalui kegiatankegiatan ekonomis, yang dilaksanakan secara bersama bagi kemanfaatan bersama". Sebagai badan usaha, Koperasi tentu dalam melakukan kegiatan usahanya juga mempunyai tujuan untuk mendapatkan keuntungan/ laba. Keuntungn/laba yang dimaksud menurut istilah dalam koperasi disebut dengan Sisa Hasil Usaha ( SHU).

Menurut Sudarmiani (2009:36) “Dalam Koperasi, pendapatan yang diperoleh dalam satu tahun dikurangi dengan penyusutan dan biaya dari tahun buku yang bersangkutan 
disebut sebagai sisa hasil usaha".

Dalam perolehan SHU setiap tahunnya tentu berbeda, tergantung besarnya partisipasi modal dan transaksi anggota terhadap pembentukan pendapatan koperasi. Semakin besar transaksi (usaha dan modal) anggota dengan koperasinya, maka akan semakin besar SHU yang akan diperoleh koperasi tersebut.

SHU yang diperoleh koperasi dalam satu tahun akan dibagikan lagi kepada anggota. "Pembagian SHU diatur menurut jasa masing- masing anggota". (Ninik dan Sunindhia 2003: 157).

Apabila jasa seorang anggota besar, yaitu jumlah transaksi yang dilakukan dengan koperasi besar maka dia juga akan menerima pengambilan SHU yang besar, dan apabila transaksinya kecil maka penerimaan SHU jugakecil.

Setiap koperasi mempunyai usaha yang berbeda-beda. Misalnya usaha pertokoan, unit usaha simpan pinjam/kredit dll. Didalam unit usaha simpan pinjam koperasi disini berperan sebagai Debitur yaitu memberikan pinjaman/kredit kepada anggota yang membutuhkannya.

Berdasarkan undang-undang nomer 17 tahun 2012 pasal 1 tentang perkoperasian, unit usaha simpan pinjam adalah salah satu unit usaha koperasi non-koperasi Simpan Pinjam yang dilaksanakan secara konvensional atau syariah.

Menurut Tohar (1999:89) "Tujuan Kredit adalah untuk memperoleh hasil keuntungan dari bunga kredit yang dibebankan kepada kreditur dengan aman tanpa hambatan". Jadi dengan pemberian kredit kepada anggota maka koperasi akan memperoleh keuntungan dari bunga kredit. Semakin banyak anggota yang meminjam maka modal koperasi juga akan bertambah.

Di dalam jasa usaha yang dikelola koperasi yang sering banyak orang ketahui adalah jenis usaha simpan pinjam/kredit. Dalam unit usaha simpan pinjam koperasi harus mempunyai cara agar anggota tertarik untuk berhutang pada koperasinya, misal, dengan menetapkan suku bunga yang rendah dan syarat- syarat kredit yang mudah. Jadi semakin besar jumlah kredit/pinjaman anggota, maka semakin besar pula jumlah SHU yang akan diterima oleh koperasi.

Setiap pegawai negeri dianjurkan untuk membentuk dinas masing-masing maka guruguru se-Kecamatan Jati membentuk koperasi dengan Nama Koperasi "MARGA JAYA".

Usaha yang dilaksanakan KPRI "MARGA JAYA" Doplang adalah usaha Simpan Pinjam dan Pertokoan. Dalam unit usaha Simpan Pinjam Semua anggota berhak untuk mendapatkan pinjaman dari koperasi tersebut. Setiap bulan bagi anggota yang mengajukan pinjaman dapat menerima pinjaman sekitar 3 kali simpanan pokok dan wajib, dengan memperhatikan kondisi keuangan dan banyaknya anggota yang mengajukan pinjaman pada bulan tersebut.

Untuk unit usaha Simpan Pinjam ada 2 macam yaitu jangka pendek dan jangka panjang. Untuk Jangka pendek 10 bulan, sedangkan untuk jangka panjang 36 bulan, Selain itu untuk unit barang anggota bisa berhutang dan pembayarannya, koperasi memotong gaji setiap bulannya sesuai dengan besarnya kredit anggota.

\section{Sisa Hasil Usaha (SHU)}

a. Pengertian SHU

Menurut Anoraga dan Sudantoko (2002: 79) Sisa Hasil Usaha Koperasi merupakan pendapatan koperasi yang diperoleh dalam satu tahun buku dikurangi dengan biaya, penyusutan, dan kewajiban lainnya termasuk pajak dalam tahun buku yang bersangkutan.

Sedangkan Menurut Sudarmiani (2009: 36) "Pendapatan yang diperoleh dalam satu tahun dikurangi dengan penyusutan dan biaya dari tahun buku yang bersangkutan disebut sebagai Sisa Hasil Usaha".

Menurut undang-undang No.25/1992, tentang perkoperasian, 
Bab IX pasal 45 (dalam sitio dan Tamba 2001: 87) adalah sebagai berikut :

1) SHU koperasi adalah pendapatan koperasi yang diperoleh dalam satu tahun buku dikurangi dengan biaya, penyusutan, dan kewajiban lain termasuk pajak dalam tahun buku yang bersangkutan.

2) SHU setelah dikurangi dana cadangan, dibagikan kepada anggota sebanding jasa usaha yang dilakukan oleh masing-masing anggota dengan koperasi, serta digunakan untuk keperluan pendidikan perkoperasian dan keperluan koperasi, sesuai dengan keputusan rapat anggota.

3) Besarnya pemupukan modal dana cadangan ditetapkan dalam rapat anggota.

Dari uraian tersebut dapat disimpulkan bahwa SHU adalah pendapatan/keuntungan koperasi selama satu tahun, setelah dikurangi biaya-biaya. SHU kemudian dibagikan kepada anggota sebanding dengan jasa yang diberikannya. Tetapi tidak semua SHU dibagikan kepada anggota, sebagian digunakan untuk dana cadangan. Besarnya dana cadangan ditetapkan dalam Rapat anggota.

Perhitungan SHU bagian anggota dapat dilakukan bila beberapa informasi dasar diketahui sebagai berikut :

1) SHU Total koperasi adalah sisa hasil usaha yang terdapat pada neraca atau laporan laba/rugi koperasi setelah pajak. Informasi ini diperoleh dari neraca atau laporan laba/rugi koperasi.

2) Transaksi Anggota adalah kegiatan ekonomi (jual-beli barang atau jasa), antara anggota terhadap koperasinya. Dalam hal ini posisi anggota adalah sebagai pemakai ataupun pelanggan koperasi. Informasi ini diperoleh dari pembukuan (buku penjualan dan pembelian) koperasi ataupun dari buku transaksi usaha anggota.

3) Partisipasi Modal adalah kontribusi anggota dalam memberi modal koperasinya, yaitu dalam bentuk simpanan pokok, simpanan wajib, simpanan usaha, dan simpanan lainnya. Data ini didapat dari buku simpanan anggota.

4) Omzet atau Volume Usaha adalah total nilai penjualan atau penerimaan dari barang dan atau jasa pada suatu periode waktu atau tahun buku yang bersangkutan.

5) Bagian (presentase) SHU untuk simpanan anggota adalah SHU yang diambil dari SHU bagian anggota, yang ditunjukkan oleh jasa modal anggota.

6) Bagian (presentase) SHU untuk transaksi usaha anggota adalah SHU yang diambil dari SHU bagian anggota, yang ditujukan untuk jasa transaksi anggota.

Pada akhir tahun, setelah memperhitungkan berbagai macam biaya dan ternyata berdasarkan perhitungan itu terdapat keuntungan, maka keuntungan itu setelah dikurangi dana cadangan akan dibagikan kepada para anggotanya sebanding dengan jasa usaha yang dilakukan oleh masingmasing anggota kepada koperasi, sesuai dengan keputusan Rapat Anggota. yang dimaksud dengan jasa usaha adalah transaksi usaha dan partisipasi modal.

Menurut Anoraga dan Sudantoko (2002: 79) pembagian sisa hasil usaha yang diselenggarakan oleh koperasi diatur pembagiannya sebagai berikut:

1) Sisa hasil usaha yang berasal dari usaha yang diselenggarakan oleh anggota dibagikan untuk:

a) Cadangan koperasi

b) Para anggota sebanding dengan jasa usaha yang diberikan oleh masingmasing anggota.

c) Dana pengurus

d) Dana pegawai atau karyawan

e) Dana pendidikan koperasi 
f) Dana social

g) Dana pembangunan daerah kerja

2) Sisa hasil usaha yang berasal dari usaha yang diselenggarakan oleh bukan anggota dibagikan untuk:

a) Cadangan koperasi

b) Dana pengurus

c) Dana pegawai

d) Dana pendidikan koperasi

e) Dana social

f) Dana pembangunan daerah kerja

Dari penjelasan diatas dapat disimpulkan bahwa pembagian SHU yang diselenggarakan oleh koperasi juga diatur pembagiannya yaitu SHU yang berasal dari usaha yang diselenggarakan anggota dan SHU dari usaha yang diselenggarakan bukan anggota. untuk SHU yang bukan dari anggota tidak boleh dibagikan kepada anggota.

b. Prinsip-Prinsip Pembagian SHU Koperasi Agar tercermin azas keadilan, demokrasi, tranparasi, dan sesuai dengan prinsip-prinsip koperasi, maka perlu diperhatikan prinsip-prinsip pembagian SHU sebagai berikut:

1) SHU yang dibagi adalah yang bersumber dari anggota.

Pada hakikatnya SHU yang dibagi kepada anggota adalah yang bersumber dari anggota sendiri, sedangkan SHU yang bukan berasal dari anggota dijadikan sebagai cadangan koperasi. Oleh sebab itu. Langkah pertama dalam pembagian SHU adalah memilahkan antara SHU yang bersumber dari hasil transaksi anggota dan SHU yang bersumber dari nonanggota.

2) SHU anggota adalah jasa dari modal dan transaksi usaha yang dilakukan anggota sendiri.

SHU yang diterima setiap anggota pada dasarnya merupakan insentif dari modal yang diinvestasikannya dan dari hasil transaksi yang dilakukannya dengan koperasi. Oleh sebab itu, perlu ditentukan proporsi SHU untuk jasa modal dan jasa transaksi usaha yang dibagi kepada anggota.

3) Pembagian SHU anggota dilakukan secara transparan.

Proses perhitungan SHU per anggota dan jumlah SHU yang dibagi kepada anggota harus diumumkan secara transparan, sehingga setiap anggota dapat dengan mudah menghitung secara kuantitatif berapa partisipasinya kepada koperasinya. Prinsip ini pada dasarnya juga merupakan salah satu proses pendidikan bagi anggota koperasi dalam membangun suatu kebersamaan, kepemilikan terhadap suatu badan usaha, pendidikan dalam proses demokrasi.

4) SHU anggota dibayar secara tunai

SHU per anggota harus diberikan secara tunai, karena dengan demikian koperasi membuktikan dirinya sebagai badan usaha yang sehat kepada anggota dan masyarakat mitra bisnisnya.

Dari penjelasan di atas dapat disimpulkan bahwa prinsip-prinsip pembagian SHU adalah yang bersumber dari anggota, dari jasa modal dan transaksi usaha yang dilakukan oleh anggota sendiri. Pembagian SHU anggota juga harus dilakukan secara transparan dan dibayar secara tunai.

\section{Pemberian Kredit}

a. Pengertian Kredit

Menurut Tohar (2001: 87) "Kredit Berasal dari bahasa latin "credere" yang berarti percaya. Dasar pemberian kredit adalah adanya kepercayaan. Jadi pihak yang memberi kredit (kreditur) percaya bahwa penerima kredit (debitur) akan sanggup memenuhi segala sesuatu yang telah dijanjikan baik menyangkut jangka waktunya, maupun prestasi dan kontra prestasinya.

Sedangkan menurut Kasmir (2008: 97) dalam artian luas kredit diartikan sebagai 
kepercayaan. Begitu pula dalam bahasa latin kredit berarti "credere" artinya percaya. Maksud dari percaya bagi si pemberi kredit adalah ia percaya kepada si penerima kredit bahwa kredit yang disalurkannya pasti akan dikembalikan sesuai perjanjian. Sedangkan bagi si penerima kredit merupakan penerimaan kepercayaan sehingga mempunyai kewajiban untuk membayar sesuai jangka waktu.

Sedangkan menurut segi ekonomi kredit adalah penundaan pembayaran dari prestasi yang diberikan sekarang, baik dalam bentuk barang, uang, maupun jasa keuntungan atau bunga yang diperoleh dari pemberi kredit yang dianggap layak diperoleh kreditur dari debitur untuk memelihara kelangsungan usaha dan memperluas usahanya.

Dari pengertian diatas dapat disimpulkan bahwa kredit adalah penyediaan uang untuk hal pinjam meminjam antara pemberi kredit (kreditur) dengan penerima kredit (debitur). Bagi pemberi kredit percaya bahwa penerima kredit akan sanggup melunasi hutangnya sesuai dengan perjanjian. Dalam hal ini harus ada unsur kepercayaan antara si pemberi kredit dengan si penerima kredit.

\section{b. Unsur-unsur Kredit}

Menurut Kasmir (2008: 98) Adapun unsur-unsur yang terkandung dalam pemberian suatu fasilitas kredit adalah sebagaiberikut :

\section{1) Kepercayaan}

Yaitu suatu keyakinan pemberi kredit bahwa kredit yang diberikan (berupa uang, barang atau jasa) akan benar-benar diterima kembali di masa tertentu di masa datang.

2) Kesepakatan

Di samping unsur percaya didalam kredit juga mengandung unsure kesepakatan antara si pemberi kredit dengan si penerima kredit. Kesepakatan ini dituangkan dalam suatu perjanjian di mana masing-masing pihak menandatangani hak dan kewajiban masing-masing.

\section{3) Jangka waktu}

Setiap kredit yang diberikan memiliki jangka waktu tertentu, jangka waktu ini mencangkup masa pengem-balian kredit yang telah disepakati. Jangka waktu tersebut bisa berbentuk jangka pendek, jangka menengah atau jangka panjang.

4) Risiko

Adanya suatu tenggang waktu pengembalian akan menyebabkan suatu risiko tidak tertagihnya/ macet pemberian kredit. Semakin panjang suatu kredit semakin besar resikonya, demikian pula sebaliknya.

5) Balas jasa

Merupakan keuntungan atas pemberian suatu kredit atau jasa tersebut yang kita kenal dengan nama bunga. Balas jasa dalam bentuk bunga dan biaya admi-nistrasi kredit ini merupakan keuntungan bank.

Sedangkan menurut Tohar (2001: 88) unsur-unsur kredit adalah sebagai berikut :

1) Kepercayaan

Suatu keyakinan pemberi kredit bahwa prestasi (uang, jasa, atau barang) yang diberikannya akan benar-benar diterimanya kembali di masa yang akan datang.

2) Waktu

Bahwa antara pemberian prestasi dan pengembaliannya dibatasi oleh waktu tertentu. Dalam unsure waktu ini terkan-dung pengertian tentang nilai agio uang yaitu bahwa uang sekarang lebih bernilai dari uang di masa yang akan datang.

3) Degree of Risk

Pemberian kredit menimbulkan suatu tingkat risiko. Risiko timbul bagi pemberi, karena uang, jasa atau barang yang berupa prestasi lepas kepada orang lain.

4) Prestasi

Yang diberikan dalam kredit adalah suatu prestasi yang dapat berupa barang, jasa, atau uang. Dalam perkembangan perkreditan di alam modern ini, yang dimaksudkan dengan prestasi dalam pemberian kredit adalah uang.

Dari penjelasan di atas maka dapat disimpulkan bahwa dalam memberikan kredit 
bagi si pemberi kredit dan si penerima kredit harus memperhatikan unsure-unsur kredit, agar tidak disalahgunakan. Dalam Unsurunsur kredit terdapat adanya kepercayaan, kesepakatan bersama, serta jangka waktu yang telah disepakati. Bahkan juga adanya risiko dan keuntungan yang berasal dari bunga kredit.

\section{c. Tujuan Kredit}

Menurut Tohar (2001: 89) Tujuan kredit adalah untuk memperoleh hasil keuntungan dari bunga kredit yang dibebankan kepada kreditur dengan aman tanpa hambatan. Sedangkan menurut Kasmir (2008: 100) Adapun tujuan utama pemberian suatu kredit adalah sebagai berikut :

\section{1) Mencari keuntungan}

Yaitu bertujuan untuk memperoleh hasil dari pemberian kredit tersebut. Hasil tersebut terutama dalam bentuk bunga yang diterima oleh bank sebagai bals jasa dan biaya administrasi kredit yang dibebankan kepada nasabah.

2) Membantu usaha nasabah

Tujuan lainnya adalah untuk membantu usaha nasabah yang memerlukan dana, baik dana investasi maupun dana untuk modal kerja. Dengan dana tersebut, maka pihak debitur akan dapat mengembangkan dan memperluaskan usahanya.

3) Membantu pemerintah

Bagi pemerintah semakin banyak kredit yang disalurkan oleh pihak perbankan, maka semakin baik, mengingat semakin banyak kredit berarti adanya peningkatan pembangunan di berbagai sector.

Dari penjelasan diatas dapat disimpulkan bahwa tujuan kredit pada umumnya adalah untuk memperoleh keuntungan. Keuntungan yang dimaksud adalah bungan dari kredit yang dibebankan kepada kreditur. Selain mencari keuntungan, tujuan kredit lainnya adalah membantu usaha nasabah dan membantu pemerintah. Semakin banyak kredit berarti pembangunan diberbagai sector juga meningkat.

\section{d. Fungsi Kredit}

Dalam kehidupan perekonomian dan perdagangan, fungsi kredit antara lain sebagai berikut:

1) Meningkatkan daya guna uang

Memberikan pinjaman uang kepada pengusaha yang memerlukan dana untuk kelangsungan usahanya berarti mendayagunakan uang secara benar.

2) Meningkatkan peredaran dan lalu lintas uang

Pemberian kredit uang yang disalurkan melalui rekening giro dapat menciptakan adanya alat pembayaran yang baru seperti bilyet giro, cek, wesel, dsb. Ini berarti ada peningkatan peredaran uang giral. Pemberian kredit uang dalam bentuk tunai juga meningkatkan daya guna peredaran uang kartal.

3) Meningkat daya guna dan peredaran barang

Para pengusaha di bidang industry memerlukan banyak modal untuk membiayai usahanya. Sebagian dari pengusaha itu ada yang menggunakan modal dari kredit (pinjaman). Dengan uang pinjaman itu mereka menjalankan usaha membeli bahan baku yang kemudian memproses bahan baku menjadi barang jadi sehingga daya guna barang itu meningkat.

4) Sebagai salah satu stabilitas ekonomi

Untuk meningkatkan keadaan ekonomi dari keadaan kurang sehat ke keadaan yang lebih sehat, biasanya kebijaksanaan pemerintah diarahkan kepada usaha-usaha untuk memenuhi kebutuhan pokok masyarakat, mengendalikan inflasi, dan mendorong kegiatan ekspor.

5) Meningkatkan kegairahan berusaha

Kemampuan para pengusaha untuk mengadakan modal sendiri bagi usahanya sangat terbatas bila dibandingkan dengan keinginan dan peluang yang ada untuk memperluas usahanya. Untuk itu pemberian kredit dapat lebih meningkatkan kegairahan berusaha.

6) Meningkatkan pemerataan pendapatan Para pengusaha dapat memperluas 
usahanya dengan bantuan modal dari kredit bank. Biasanya perluasan usaha ini memerlukan tenaga kerja tambahan. Hal ini sama saja dengan membuka kesempatan kerja, juga membuka peluang adanya pemerataan pendapatan.

7) Meningkatkan hubungan internasional

Bantuan kredit dapat diselenggarakan dalam negeri maupun luar negeri. Perusahaan dalam negeri mempunyai kemungkinan untuk menerima bantuan kredit dari bank atau lembaga keuangan luar negeri, demikian pula sebaliknya. Tohar(2001:90-91).

Dari penjelasan di atas dapat disimpulkan bahwa fungsi kredit bermacammacam, yaitu meningkatkan daya guna uang, meningkatkan peredaran dan lalu lintas uang, meningkat daya guna dan peredaran barang, sebagai salah satu stabilitas ekonomi, meningkatkan kegairahan berusaha, meningkatkan pemerataan pendapatan dan meningkatkan hubungan internasional.

\section{e. Jenis kredit}

Ada berbagai jenis kredit yang dapat dilihat dari berbagai sudut. Jenis-jenis kredit tersebut antara lain sebagai berikut :

1) Dari segi Lembaga Pemberi dan Penerima Kredit

Dari segi lembaga pemberi dan penerima, dapat dibedakan tiga jenis kredit. Ketiga jenis kredit tersebut adalah sebagai berikut:

a) Kredit Perbankan

Kredit perbankan adalah pemberian kredit dari bank kepada masyarakat untuk kegiatan usaha dan atau konsumsi. Kredit ini diberikan oleh bank pemerintah atau bank swasta untuk ikut membiayai sebagian kebutuhan permodalan.

b) Kredit Likuiditas

Kredit Likuiditas adalah kredit yang diberikan oleh bank sentral kepada bank-bank yang beroperasi di Indonesia, yang selanjutnya digunakan untuk membiayai kegiatan perkreditan. c) Kredit Langsung

Kredit ini diberikan oleh Bank Indonesia kepada lembaga pemerintah atau semi pemerintah.

2) Dari Segi Tujuannya

Dari segi tujuannya juga dapat dibedakan tiga macam kredit, yaitu:

a) KreditKonsumtif

Kredit Konsumtif adalah kredit yang diberikan oleh bank pemerintah atau bank swasta kepada perseorangan untuk membiayai keperluan konsumsinya dalam kebutuhan sehari-hari.

b) KreditProduktif

Kredit Produktif adalah kredit yang diberikan untuk tujuan memperlancar jalannya proses produksi.

c) Kredit Semi-konsumtif dan kredit semi- produktif

3) Dari Segi Dokumen

Dari segi dokumen dikenal dua macam kredit, Kedua macam kredit tersebut adalah :

a) KreditEkspor

Kredit ekspor adalah semua bentuk kredit sebagai sumber pembiayaan bagi usaha ekspor.

b) Kredit Impor

Kredit impor yaitu semua bentuk kredit sebagai sumber pembiayaan bagi usaha impor

4) Dari Segi Besar Kecilnya Aktivitas Pemutaran Usahanya

Dari segi besar kecilnya aktivitas pemutaran usaha dikenal tiga jenis kredit. Ketiga jenis kredit tersebut adalah kredit kecil, menengah, dan besar.

a) KreditKecil

Kredit kecil yaitu kredit yang diberikan kepada pengusaha yang tergolong sebagai pengusaha kecil.

b) Kredit Menengah

Kredit menengah yaitu kredit yang diberikan kepada pengusaha yang tergolong pengusaha menengah.

c) Kredit Besar

Kredit besar yaitu kredit yang diberikan 
kepada pengusaha yang tergolong sebagai pengusaha besar.

5) Dari Segi Jangka Waktunya

Dari segi jangka waktunya, dikenal tiga macam jenis kredit, yaitu:

a) Kredit Jangka Pendek Kredit jangka pendek yaitu kredit yang berjangka waktu maksimum 1 (satu) tahun.

b) Kredit Jangka Menengah yaitu kredit yang diberikan jangka waktunya antara 1 sampai dengan 3 tahun.

c) Kredit Jangka Panjang yaitu kredit yang jangka waktunya lebih dari 3 tahun.

6) Ditinjau Dari Segi Jaminannya

Ditinjau dari jaminannya, dibedakan duajenis kredit, yaitu :

a) Kredit tanpa jaminan yaitu kredit yang diberikan oleh bank atau lembaga keuangan tanpa menyerahkan jaminan.

b) Kredit dengan jaminan yaitu semua kredit yang diberikan oleh lembaga keuangan dengan jaminan tertentu. Jaminan dalam jenis kredit ini bisa berupa jaminan barang, baik berupa barang tetap atau harta yang tidak bergerak maupun barang tidak tetap atau harta bergerak, jaminan surat berharga (efek), baik berupa saham dan sertifikat yang terdaftar dibursa efek, dan jaminan pribadi atau orang, yaitu suatu pihak atau seseorang yang menyanggupi untuk pihak lain dalam hal pembayaran hutang apabila pihak lain selaku debitur tidak melakukan atau menepati kewajibannya.

7) Dari Segi Penggunaanya

Dari segi penggunaanya, dikenal berbagai macam jenis kredit. Jenis-jenis kredit tersebut adalah dibedakan menjadi 9 kredityaitu :

a) Kredit Aksploitasi, yaitu pemberian kredit jangka pendek oleh suatu bank kepada perusahaan untuk membiayai kebutuhan modal kerja.

b) Kredit investasi, yaitu kredit yang berjangka waktu menengah dan panjang yang diberikan bank kepada perusahaan untuk melakukan investasi atau penanaman modal.

c) Kredit usaha kecil, yaitu kredit yang diberikan kepada pedagang golongan menengah kebawah.

d) Pinjaman komersial, yaitu pemberian kredit untuk tujuan perdagangan komersial.

e) Pinjaman konsumen, yaitu pemberian kredit untuk tujuan konsumtif.

f) Kredit modal kerja, yaitu pemberian kredit untuk tujuan modal usaha.

g)Kredit kepemilikan rumah, yaitu pemberian kredit untuk tujuan pembelian rumah.

h) Kredit kepemilikan mobil, yaitu pemberian kredit untuk tujuan pembelian mobil.

i) Kredit likuiditas bank Indonesia, kredit dari bank Indonesia yang diperuntukkan bagi bank-bank pemerintah dan swasta guna disalurkan lagi ke berbagai sector.

8) Menurut Pembayarannya

Berdasarkan cara pembayarannya, dibedakan enam jenis kredit, yaitu :

a) Pinjaman Angsuran, yaitu pinjaman yang pengembaliannya melalui angsuran secara bertahap

b) Pinjam Tetap, yaitu pinjaman dengan cara pengembalian pokok pinjaman menurut jangka waktu tertentu

c) Demand Loand, yaitu pinjaman yang dapat ditarik sewaktu-waktu sesuai fasilitas yang tersedia dan pengembaliannya menurut jangka waktu tertentu

d)Pinjaman Rekening Koran, yaitu fasilitas kredit yang disediakan oleh bank sesuai mutasi rekening nasabah yang terutama ditujukan untuk menunjang transaksi perdagangannya

e) Pinjaman Promes, yaitu pinjaman yang didasarkan atas jaminan promes sesuai nominal maupun jatuh tempo pembayarannya 
f) Pinjaman Call Money, yaitu pinjaman antar bank yang pembayarannya didasarkan atas nominal atau jangka temponya sesuai tingkat bunga yang disepakati

9) Menurut Sifatnya

Menurut sifatnya dibedakan dua jenis kredit, yaitu:

a) Pinjaman Sindikasi yaitu pembiayaan bersama beberapa bank untuk membiayai sebuah project financing. Tingkat suku bunganya didasarkan atas inter bank offerd rate, baik sibor maupun labor

b) Off Shore Loan (Pinjaman Luar Negeri) adalah pinjaman dari luar negeri yang dipergunakan untuk pembayaran suatu proyek dengan tingkat suku bunga yang didasarkan atas inter bank offerd rate, baik sibor maupun libor. Tohar (2001: 91-96).

Dari penjelasan diatas dapat disimpulkan bahwa jenis kredit bermacam-macam. Ada jenis kredit dari segi pemberi dan penerima kredit, tujuannya, dokumen, jangka waktu, jaminannya, penggunaannya, menurut pembayarannya, menurut sifatnya dsb.

\section{4) Koperasi Pegawai Republik Indonesia (KPRI)}

Menurut Arifinal Chaniago (1984: 38) Koperasi pegawai negeri adalah koperasi yang para anggotanya berpenghasilan tetap. Setiap pegawai negeri dianjurkan untuk membentuk/mendirikan koperasi di bawah lingkungan/kedinasan masing-masing. Koperasi pegawai negeri lebih mementing-kan kegiatan usaha konsumsi dan simpan pinjam.

Koperasi Pegawai Republik Indonesia (KPRI), koperasi ini beranggotakan para pegawai negeri. Sebelum KPRI, koperasi ini bernama Koperasi Pegawai Negeri (KPN). KPRI bertujuan terutama meningkatkan kesejateraan para pegawai negeri (anggota). KPRI dapat didirikan di lingkup departemen atau instansi.

http://rizkiauliadermawan1 eb15.blogspot.co m/2011/09/koperasi-koperasi-adalah-badanusaha.html

Koperasi yang anggota-anggotanya terdiri dari para pegawai negeri dalam suatu daerah kerja adalah Koperasi Pegawai Republik Indonesia. (http://rahmanug.blogspot.com/2012/10/normal-0-falsefalse-false-in-x-none-x.html)

Koperasi Pegawai Negeri (KPN). KPRI bertujuan terutama meningkatkan kesejahteraan para pegawai negeri (anggota). (http://velyrandyantini.blogspot.com/2012/1 0/pengertian-dan-jenis-jenis-koperasi.html)

Dilihat dari lapangan usahanya, Koperasi Pegawai Republik Indonesia (KPRI) adalah koperasi golongan konsumen yang berusaha memenuhi kebutuhan anggotanya dalam meningkatkan kesejahteraan para anggotanya. Dilihat dari jenisnya, KPRI termasuk jenis atau golongan koperasi fungsioinal di mana anggotanya mempunyai kesamaan profesi dan kepentingan yaitu sebagai pegawai negeri.

Berdasarkan pengertian di atas dapat disimpulkan bahwa Koperasi Pegawai Republik Indonesia (KPRI) adalah koperasi yang anggota-anggotanya terdiri dari para pegawai negeri republik Indonesia dalam suatu daerah kerja. KPRI merupakan salah satu jenis koperasi yang membutuhkan modal yang cukup untuk menggerakkan dan meningkatkan seluruh bidang usahanya.

Dari peneltian diatas dapat diketahui hubungan antara pemberian kredit dengan sisa hasil usaha pada koperasi pegawai republik indonesia (KPRI) "MARGA JAYA" di Desa Doplang Kabupaten Blora tahun 1992 -2012 .

\section{METODE PENELITIAN}

Metode penelitian yang digunakan dalam penelitian ini adalah metode kausalkomparatif. Variabel-variabel yang dilibatkan dalam penelitian ini adalah Pemberian Kredit (X) sebagai variabel bebas dan Sisa Hasil Usaha (Y) sebagai variabel terikat.

Untuk mendapatkan data yang 
diperlukan dalam penelitian ini, digunakan teknik pengumpulan data dengan studi lapangan. Studi Lapangan (Field Reseacrh), yaitu penelitian dilakukan dengan cara terjun langsung ke lokasi penelitian untuk mengetahui kondisi yang sebenarnya dari obyek penelitian. Adapun teknik yang digunakan dalam studi lapangan ini adalah :

\section{Wawancara}

Ialah teknik pengumpulan dara apabila peneliti ingin melakukan studi pendahuluan untuk menemukan permasalahan yang harus diteliti, dan juga apabila peneliti ingin mengetahui hal-hal dari responden yang lebih mendalam dan jumlah respondennya sedikit/kecil. Teknik pengumpulan data ini mendasarkan diri pada laporan tentang diri sendiri atau self-report, atau setidak-tidaknya pada pengetahuan dan atau keyakinan pribadi (Sugiyono, 2010: 194).

Dalam penelitian ini, wawancara yaitu tanya jawab secara lisan dengan pihak-pihak yang dipandang mempunyai otoritas dengan obyek penelitian. Wawancara ini diperlukan untuk mendapatkan data yang tidak mungkin digambarkan dengan angka. Wawancara dilakukan kepada Pengurus, Pengawas serta beberapa anggota KPRI "MARGA JAYA" di Doplang kabupaten Blora. Jadi dengan demikian data yang diperoleh dari wawancara lebih bersifat kualitatif.

\section{Dokumentasi}

Dokumentasi, dari asal katanya dokumen, yang artinya barang- barang tertulis. Di dalam melaksanakan metode dokumentasi peneliti menyelidiki bendabenda tertulis seperti buku-buku, majalah, dokumen, peraturan- paraturan, notulen rapat, catatan, dsb. (Arikunto, 2010: 201).

Dengan demikian, teknik pengumpulan data dengan dokumentasi ini yaitu memperoleh data dengan cara mencatat dokumen-dokumen koperasi seperti data sejarah berdirinya KPRI "Marga Jaya", $\mathrm{AD} / \mathrm{ART}$, jumlah pinjaman serta jumlah sisa hasil usaha (SHU) koperasi tahun 1992-2012.

\section{Populasi dan Sampel Peneltian}

Menurut Arikunto (2010: 173) Populasi adalah keseluruhan subjek penelitian. Sedangkan menurut Gabriel (2003: 59) Populasi adalah mencatat semua elemen yang diselidiki, menyelidiki semua obyek, semua gejala atau peristiwa.

Lain halnya dengan Sugiyono (2010: 117) yang berpendapat bahwa populasi adalah wilayah generalisasi yang terdiri atas : obyek/ subyek yang mempunyai kualitas dan karakteristik tertentu yang ditetapkan oleh peneliti untuk dipelajari dan kemudian ditarik kesimpulannya. Dengan demikian populasi dalam penelitian ini adalah Tahun buku, yaitu dari tahun 1992 - 2012 jadi jumlahnya 21 tahun.

Menurut Arikunto (2010: 174) Sampel adalah sebagian atau wakil populasi yang diteliti. Sedangkan menurut Gabriel (2003: 65) Teknik sampel adalah metode pengumpulan informasi (data) terhadap sebagian anggota populasi. Sampel harus diambil representative, artinya: mewakili seluruh populasi oleh karenanya pemilihan sampel harus diusahakan sedemikian rupa sehingga memberikan gamparan seluruh populasi.

Lain halnya dengan Sugiyono (2010: 118) Sampel adalah bagian dari jumlah dan karakteristik yang dimiliki oleh populasi tersebut. Dalam penelitian ini sampelnya berjumlah 21 tahun.

\section{Variabel Peneltian}

Dengan demikian, dalam penelitian ini terdapat 2 (dua) variabel, yaitu variabel bebas (X) berupa pemberian kredit/ pinjaman dan variabel terikat $(\mathrm{Y})$ yaitu sisa hasil usaha. Adapun definisi operasional variabelvariabel tersebut adalah sebagai berikut :

a. Pemberian kredit/pinjaman yaitu koperasi memberikan pinjaman kepada anggota sesuai dengan jumlah pinjaman.

b. Sisa hasil usaha yaitu jumlah keuntungan 
yang diperoleh koperasi selama masa operasional koperasi (biasanya setahun).

\section{Hasil Peneltian}

Dari hasil perhitungan dalam pengujian hipotesis di atas telah diperoleh angka koefisien korelasi (r) sebesar 0,93. Hal ini merupakan korelasi yang positif antara kedua variabel, yaitu hubungan antara Pemberian Kredit (X) dengan Sisa Hasil Usaha (Y) termasuk kategori Sangat Tinggi atau Kuat Sekali, dapat diandalkan. Hal ini mengandung pengertian bahwa Pemberian Kredit mempunyai peran yang sangat penting untuk meningkatkan SHU pada KPRI “ MARGAJAYA".

Di lain pihak dalam uji determinasi diperoleh nilai $\mathrm{R}^{2}$ adalah sebesar 0,865 . Jadi sumbangan dari pemberian kredit terhadap perolehan SHU koperasi yaitu sebesar $86,5 \%$ sedangkan sisanya sebesar $13,5 \%$ dipengaruhi oleh factor lain.

Menurut Ninik Widiyanti dan Y.W. Sunindhia (2003: 54) “ untuk memperbesar modal Koperasi, maka sebagian keuntungan (SHU) tidak dibagikan kepada anggota dan dicadangkan". Dengan SHU yang dicadangkan tersebut, koperasi memberikan kesempatan kepada anggota untuk memperoleh pinjaman sehingga pemberian kredit kepada anggota dapat diperluas. semakin luas pemberian kredit pada anggota maka keuntungan yang diperoleh koperasi akan meningkat. Keuntungan ( SHU) ini penting untuk kelangsungan hidup koperasi. Dengan memberikan kredit koperasi akan mendapatkan keuntungan atau dalam koperasi disebut dengan Sisa Hasil Usaha (SHU) dalam bentuk bunga yang akan diterima oleh koperasi sebagai balas jasa dan biaya administrasi kredit yang dibebankan kepada anggota yang meminjam. Untuk mencapai tujuan dari pemberian kredit, perlu adanya pengawasan terhadap penggunaan kredit yang telah diberikan, agar pinjaman yang diberikan betul-betul digunakan untuk hal-hal yang bermanfaat.
Menurut Widiyanti dan Sunindhia (2003: 53) Dalam memberikan pelayananpelayanan itu pengurus koperasi harus berusaha supaya ongkos (atau bunga) ditetapkan serendah mungkin agar dirasakan ringan oleh para anggotanya, serta syaratsyarat kredit yang mudah. Semakin banyak anggota yang meminjam maka SHU yang akan diperoleh Koperasi semakin tinggi.

\section{Hasil Analisis Data}

Dalam perhitungan uji t diperoleh nilai $\mathrm{t}_{\text {hitung }}$ sebesar 11,315, sedangkan $\mathrm{t}_{\text {tabel }}$ dengan derajat bebas $(\mathrm{db})=\mathrm{N}-(\mathrm{K}-1)$ untuk uji satu arah yaitu $\mathrm{db}=21-(2-1)=20$ adalah sebesar $1,725 \mathrm{Hal}$ ini berarti bahwa nilai $\mathrm{t}_{\text {hitung }}>\mathrm{t}_{\text {tabel }}$ $(11,315>1,725)$. Atas dasar uji t tersebut dapat disimpulkan tolak Ho (Ha diterima), artinya ada beda hubungan antara pemberian kredit dengan SHU pada KPRI "MARGA JAYA“ tahun 1992-2012. Hal ini mengandung pengertian bahwa Pemberian Kredit mempunyai peran yang sangat penting untuk meningkatkan SHU pada KPRI “ MARGA JAYA".

\section{PENUTUP \\ Simpulan}

Pemberian kredit yang diberikan kepada anggota oleh KPRI "MARGA JAYA" kurang baik. Hal ini dibuktikan untuk pemberian kredit diperoleh rata-rata (mean) sebesar 31514, 29, nilai minimum sebesar 14000 dan nilai maximum sebesar 76800 . Sedangkan dari data diatas yang memperoleh nilai diatas rata-rata (mean) > 31514,29 sebanyak 8 tahun yaitu tahun 2001, 2003, 2007, 2008, 2009, 2010, 2011, dan 2012 atau hanya $38,10 \%$. Sedangkan nilai dibawah ratarata sebanyak 13 tahun yaitu tahun 1992, 1993, 1994, 1995, 1996, 1997, 1998, 1999, 2000, 2002, 2004, 2005, 2006 atau $61,90 \%$.

Sisa hasil usaha yang diperoleh KPRI "MARGA JAYA" dikatakan kurang baik. Hal ini dibuktikan untuk sisa hasil usaha diperoleh rata-rata (mean) sebesar 3138,52, 
nilai minimum sebesar 423 dan nilai maximum sebesar 9750. Sedangkan dari data diatas yang memperoleh nilai diatas rata-rata (mean) $>3138,52$ sebanyak 8 tahun yaitu tahun 2004, 2005, 2007, 2008, 2009, 2010, 2011, dan 2012 atau hanya 38,10\%. Sedangkan nilai dibawah rata-rata sebanyak 13 tahun yaitu tahun 1992, 1993, 1994, 1995, 1996, 1997, 1998, 1999, 2000, 2001, 2002 2003, 2006 atau 61,90\%.

Pemberian Kredit mempunyai hubungan dengan perolehan SHU pada KPRI "MARGA JAYA". Terbukti dari analisis korelasi yang memuat uji korelasi product momen dan uji t. Dari hasil korelasi besarnya nilai $\mathrm{r}_{\text {hitung }}$ adalah 0,930 sedangkan $\mathrm{r}_{\text {tabel }} 0,3515$. Hal ini berarti nilai $r_{\text {hitung }}>r_{\text {tabel }}(0,930>$ 0,3515). Artinya ada hubungan antara pemberian kredit dengan sisa hasil usaha pada KPRI "MARGA JAYA" tahun 1992-2012. Selanjutnya dari hasil uji $t$ diperoleh $t_{\text {hitung }}$ sebesar 11,315, sedangkan $t_{\text {tabel }}$ dengan derajat bebas $(\mathrm{db})=\mathrm{N}-(\mathrm{K}-1)$ untuk uji satu arah yaitu $\mathrm{db}=21-(2-1)=20$ adalah sebesar 1,725 . Hal ini berarti bahwa nilai $t_{\text {hitung }}>t_{\text {tabel }}(11,315>$ 1,725). Atas dasar uji $t$ tersebut dapat disimpulkan tolak Ho, artinya ada beda hubungan antara pemberian kredit dengan SHU pada KPRI "MARGA JAYA" tahun 1992 - 2012. Hal ini juga didukung dengan analisis uji determinasi yang digunakan untuk mengetahui seberapa besar prosentase sumbangan pemberian kredit terhadap perolehan SHU. Diketahui nilai $\mathrm{R}^{2}$ adalah 0,865 . Jadi sumbangan dari pemberian kredit terhadap perolehan SHU koperasi yaitu $86,5 \%$, sedangkan sisanya sebesar $13.5 \%$ dipengaruhi oleh factor lain.

\section{Saran}

Adapun saran yang dapat dikemukakan dalam akhir penyusunan laporan penelitian ini antara lain sebagai berikut:

Untuk KPRI "MARGA JAYA" diharapkan untuk memperbanyak Pemberian Kreditnya pada anggota. agar anggota tertarik untuk mengajukan pinjaman maka dalam memberikan pelayanan - pelayanan pengurus koperasi harus berusaha supaya bunga ditetapkan serendah mungkin agar dirasakan ringan oleh para anggotanya, serta syarat syarat kredit yang mudah.

Bagi Anggota KPRI "MARGA JAYA", Lebih aktif berpartisipasi untuk meminjam, karena semakin banyak anggota yang meminjam maka SHU yang diperoleh koperasi meningkat. Anggota yang meminjam harus bisa mengembalikan tepat waktu sesuai jangka waktu yang telah ditetapkan agar tidak terjadi kredit macet. Anggota yang meminjam agar pinjaman yang diterima itu betul - betul digunakan untuk hal- hal yang bermanfaat.

Bagi peneliti selanjutnya agar melakukan penelitian dengan menggunakan variable-variabel lain selain yang diteliti dalam penelitian ini, dan diharapkan penelitian ini dapat menambah wawasan peneliti lain dimasa mendatang.

\section{DAFTAR PUSTAKA}

Arifin Sitio dan Halomoan Tamba. 2001. KOPERASI Teori dan Praktek. Jakarta: Erlangga

Chaniago, Arifinal. 1984. Perekonomian Indonesia. Bandung: ANGKASA

Husaini Usman dan Purnomo S.A. 2006. PENGANTAR STATISTIKA. Jakarta: Bumi Aksara

Iqbal Hasan. 2004. ANALISIS DATA PENELITIAN DENGAN STATISTIK. Jakarta: PT Bumi Aksara.

Kasmir. 2008. BANK dan Lembaga Keuangan Lainnya. Jakarta: PT RAJA GRAFINDO PERSADA

M. Tohar. 1999. Permodalan dan Perkreditan Koperasi. Yogyakarta: KANISIUS (Anggota IKAPI)

Ninik Widiyanti dan Sunindhia. 2003. Koperasi dan Perekonomian Indonesia. Jakarta: PT RINEKA CIPTA dan BINA ADIAKSARA 
Pandji Anogara dan Djoko Sudantoko. 2002. KOPERASI, KEWIRAUSAHAAN DAN USAHA KECIL. Jakarta: Rineka Cipta

Silalahi, G.A. 2003. Metodologi Penelitian dan Studi Kasus. Sidoarjo: Citra Media

Sudarmiani. 2009. AKUNTANSI KOPERASI Teori dan Praktek. Surabaya: Unesa University Press

Sugiyono. 2007. Metode Penelitian Kuantitatif, Kualitatif dan $R \& B$. Bandung: ALFA BETA CV Sugiyono. 2010. METODE PENELITIAN PENDIDIKAN Pendekatan Kuantitatif, Kualitatif dan $R \& B$. Bandung: ALFA BETA
Suharsimi Arikunto. 2010. PROSEDUR PENELITIAN Suatu Pendekatan Praktek. Jakarta: Rineka Cipta

UNDANG-UNDANG RI No. 17 TAHUN 2012 TENTANG PERKOPERASIAN

(http://rahman-ug.blogspot.com/ 2012/10/normal-0-false-false-false-inx-none-x.html)

http://rizkiauliadermawan1 eb15.blogspot.co $\underline{\mathrm{m} / 2011 / 09 / \text { koperasi-koperasi-adalah- }}$ badan-usaha.html

(http://velyrandyantini.blogspot.com/2012/1 0/pengertian-dan-jenis-jeniskoperasi.html)

ntini.blogspot.com/2012/10/pengertian-danjenis-jenis-koperasi.html) 